\title{
Analysis of the Expression and Modulation of Selected Immune- related Gene Transcripts in the DLEC Cell Line from European Sea Bass (Dicentrarchus labrax L.)
}

\author{
Francesco Buonocore $^{1 *}$, Elisa Randelli, Niels Lorenzen ${ }^{2}$, Katja Einer-Jensen ${ }^{2}$ and Giuseppe Scapigliati
}

${ }^{1}$ Department of Environmental Sciences, University of Tuscia, Largo dell'Università s.n.c., 01100 Viterbo, Italy

${ }^{2}$ National Veterinary Institute, Technical University of Denmark, Arhus N, Denmark

\begin{abstract}
Cell lines have been established from different fish species especially for virus isolation and for studying cell-pathogen interactions, and therefore are of interest in aquaculture. In this paper, we have investigated the presence and the regulation of some immune genes in the DLEC (Dicentrarchus labrax embryonic cells) cell line from European sea bass (Dicentrarchus labrax L.) to preliminary elucidate their action. The basal expression of the selected genes (interleukin$1 \beta$ (IL-1 $\beta$ ), cyclooxygenase-2 (COX-2), transforming growth factor- $\beta$ (TGF- $\beta$ ), CD8- $\alpha$, major histocompatibility complex II- $\beta$ (MHC II- $\beta$ ), interferon (IFN) and Mx protein (Mx)) have been investigated and, successively, their modulation have been studied both after stimulation with different mitogen agents and after a transfection with a sequence codifying for the coat protein of a fish nervous necrosis virus (NNV). The results have evidenced that the inflammatory molecules (IL-1 $\beta$, COX-2, TGF- $\beta$ ), constitutively expressed by the DLEC cell line, are not up-regulated by the stimulation with lipopolysaccharide (LPS) from E. coli, whether the expression of the T-cell marker transcripts (CD8- $\alpha$, MHC II- $\beta$ ) is influenced by the action of a lectin from Phaseolus vulgaris (PHA-L). Finally, the expression of the coat NNV protein in the DLEC cell line, after the transfection, led to an high up-regulation of IFN and Mx gene transcripts. These data suggest that the DLEC cell line recognize specific pathogen-associated molecular patterns (PAMPs) and, therefore, could be useful for studying T-cell pathways and viral responses in sea bass avoiding the use of live test animals.
\end{abstract}

Keywords: Sea bass; DLEC cell line; Immune transcripts; Real time; Aquaculture

Abbreviations: DLEC: Dicentrarchus Labrax Embryonic Cells; IL-
1 $\beta$ : Interleukin-1 $\beta$; COX-2: Cyclooxygenase-2; TGF- $\beta$ : Transforming
Growth Factor- $\beta$; MHC II- $\beta$ : Major Histocompatibility Complex II-
$\beta$; IFN: Interferon; Mx: Mx protein; NNV: Nervous Necrosis Virus;
LPS: Lipopolysaccharide; PHA-L: Phaseolus vulgaris Leucoagglutinin;
PAMPs: Pathogen-Associated Molecular Patterns; PRRs: Pathogen
Recognition Receptors; PBS: Phosphate Buffered Saline; TLR: Toll-Like
Receptor

\section{Introduction}

Cell lines are an important biological instrument for carrying out studies into animal physiology, virology and toxicology without using live test animals and usually provide highly reproducible results. During last decades, many continuous cell lines have been obtained from Teleost fish species due to their possible applications in both biomedical sciences and aquaculture [1]. They have been developped both from a wide range of tissues (ovary, fin, swim bladder, liver, head kndney, ecc.) and from embryonic stem (ES) cells. Most of the cell lines were applied in virological $[2-4]$ and bacterial $[5,6]$ studies and tested in transfection experiments, to determine their potential utility in transgenic and genetic manipulation research projects $[3,6]$.

European sea bass (Dicentrarchus labrax L.) is one of the most important marine fish species in the South Mediterranean area and two cell lines have been obtained for this species: the so called DLEC cell line from embryonic cells [7] and long term cultures from neural stem cells of adult sea bass [8]. In this paper we investigated the basal expression of selected immuno-relevant genes in the DLEC cell line and studied their modulation after both stimulations with various mitogen agents and a transfection with a plasmid containing the sequence codifying for the coat protein of a fish nervous necrosis virus (NVV).

The interaction between pathogens and their hosts is initiated by the activation of pathogen recognition receptors (PRRs). These receptors recognize specific pathogen-associated molecular patterns (PAMPs) and activate the immune responses. The aim of our study was to provide new insights in the response of the DLEC cell line to PAMPs and, therefore, to evidence the importance of this cell line in research projects related both to fish immunology and aquaculture.

\section{Materials and Methods}

\section{Cell culture}

$5 \times 10^{6}$ DLEC cells were plated in $50 \mathrm{ml}$ flasks with $5 \mathrm{ml}$ of Leibovitz L-15 meidum (Gibco, Grand Island, New York, USA) containing 10\% (v/v) fetal calf serum (Gibco, Grand Island, New York, USA). Every 48 hours adherent cells were washed with phosphate buffered saline (PBS) and detached with tripsin-EDTA (Sigma-Aldrich, St. Louis, MO, USA) prior to add fresh medium as described before [7].

\section{Cloning and sequencing of the selected gene of interest from DLEC}

Total RNA was extracted from DLEC cells with TRIsure (Bioline, London, UK) following the manufacturer's instructions and

*Corresponding authors: Dr. Francesco Buonocore, Dipartimento di Scienze Ambientali, Università della Tuscia, Largo dell'Università s.n.c., I-01100 Viterbo, Italy, Tel : +39-0761-357644; Fax+39-0761-357179; E-mail: fbuono@unitus.it

Received November 05, 2010; Accepted December 14, 2011; Published January 05, 2011

Citation: Buonocore F, Randelli E, Lorenzen N, Einer-Jensen K, Scapigliati G (2011) Analysis of the Expression and Modulation of Selected Immune-related Gene Transcripts in the DLEC Cell Line from European Sea Bass (Dicentrarchus labrax L.). J Aquac Res Development 2:105. doi:10.4172/2155-9546.1000105

Copyright: (c) 2011 Buonocore F, et al. This is an open-access article distributed under the terms of the Creative Commons Attribution License, which permits unrestricted use, distribution, and reproduction in any medium, provided the original author and source are credited. 
Citation: Buonocore F, Randelli E, Lorenzen N, Einer-Jensen K, Scapigliati G (2011) Analysis of the Expression and Modulation of Selected Immunerelated Gene Transcripts in the DLEC Cell Line from European Sea Bass (Dicentrarchus labrax L.). J Aquac Res Development 2:105. doi:10.4172/2155-9546.1000105

resuspended in DEPC treated water. For cDNA synthesis, $1 \mu \mathrm{g}$ of total RNA and $0.5 \mu \mathrm{g}$ of random primers $\left[\mathrm{pd}(\mathrm{N})_{6}\right]$ were used in each reverse transcription reaction in a total volume of $50 \mu$. The presence of the selected immuno-related genes (IL- $1 \beta$, COX-2, TGF- $\beta$, CD8- $\alpha$, MHC II- $\beta$, IFN and $\mathrm{Mx}$ ) was tested by PCR on the cDNA using the primers pairs indicated in Table I. The cycling protocol was one cycle of $94^{\circ} \mathrm{C}$ for $5 \mathrm{~min}, 35$ cycles of $94^{\circ} \mathrm{C}$ for $45 \mathrm{~s}, 52^{\circ} \mathrm{C}$ for $45 \mathrm{~s}, 72^{\circ} \mathrm{C}$ for $45 \mathrm{~s}$, followed by one cycle of $72^{\circ} \mathrm{C}$ for $10 \mathrm{~min}$. Reactions were conducted using the Mastercycler personal (Eppendorf, Hamburg, Germany). PCR products $(15 \mu \mathrm{l})$ were visualised on $1 \%(\mathrm{w} / \mathrm{v})$ agarose gels containing ethidium bromide $(10 \mathrm{ng} / \mathrm{ml})$ using hyperladder IV (Bioline London, UK) as size marker. Controls for the presence of DNA contamination were performed using the RNA sample as template. DNA amplified by PCR was purified using the QIAquick Gel Extraction Kit (QIAgen, Hilden, Germany), inserted into the pGEM-T Easy vector (Promega, Madison, WI, USA) and transfected into competent JM109 Escherichia coli cells. Plasmid DNA from at least five independent clones was purified using the Wizard Plus SV Minipreps DNA Purification System (Promega, Madison, WI, USA) and sequenced using Eurofins MWG Operon DNA Sequencing Services (Ebersberg, Germany). Sequences generated were analysed for similarity with other known sequences using the FASTA [9] and BLAST [10] programs.

\section{DLEC stimulation and transfection}

Three $50 \mathrm{ml}$ flasks with $5 \times 10^{6}$ DLEC cells were stimulated with different mitogen agents at different time points: 1) $5 \mathrm{mg} / \mathrm{ml}$ of lipopolysaccharide (LPS from E. coli 0127:B8, Sigma-Aldrich, St. Louis, MO, USA) in PBS at $18^{\circ} \mathrm{C}$ for $4 \mathrm{~h}$ and $24 \mathrm{~h}$, the control was stimulated with PBS only; 2) $1 \mu \mathrm{g} / \mathrm{ml}$ of lectin from Phaseolus vulgaris Leucoagglutinin (PHA-L from Sigma-Aldrich, St. Louis, MO, USA) in PBS at $18^{\circ} \mathrm{C}$ for $4 \mathrm{~h}$ and $24 \mathrm{~h}$, the control was stimulated with PBS only. Moreover, the DLEC cells were transfected with: 1) $3 \mu \mathrm{g}$ of a pcDNA3 vector (Invitrogen, Grand Island, New York, USA) containing the nucleotide sequence codifying for the coat protein of a fish nervous necrosis virus (NNV, accession number YP_611157) and 2) $3 \mu \mathrm{g}$ of with pcDNA3 without insert. The transfections were performed with the Transfectam Reagent (Promega, Madison, WI, USA) following the kit instructions. Positive cells were selected by continuous incubation in L-15 medium containing Geneticin G-418 (Sigma-Aldrich, St. Louis, $\mathrm{MO}, \mathrm{USA}$ ) at $1.2 \mathrm{ng} / \mathrm{ml}$ added $48 \mathrm{~h}$ after the transfection as described before [7].

Real-time PCR quantitative analyses of the DLEC cells after stimulation and transfection

Total RNA was isolated from each DLEC flask stimulated separately

\begin{tabular}{|l|l|l|}
\hline GENE & PRIMERS (FORWARD AND REVERSE) & $\begin{array}{l}\text { EMBL ACCESSION } \\
\text { NUMBER }\end{array}$ \\
\hline $\boldsymbol{\beta}$-actin & $\begin{array}{l}\text { 5'-ATGTACGTTGCCATCC-3' } \\
\text { 5'-GAGATGCCACGCTCTC-3' }\end{array}$ & AJ493428 \\
\hline rRNA 18S & $\begin{array}{l}\text { 5'-CCAACGAGCTGCTGACC-3' } \\
\text { 5'-CCGTTACCCGTGGTCC-3' }\end{array}$ & AY831388 \\
\hline IL-1 $\boldsymbol{\beta}$ & $\begin{array}{l}\text { 5'-GGTGGACAAAGCCAGTC-3' } \\
\text { 5'-CCGAGCCTTCAACATCG-3' }\end{array}$ & AJ331925 \\
\hline $\mathbf{C O X - 2}$ & $\begin{array}{l}\text { 5'-CATTCTTTGCCCAGCACTTCACC-3' } \\
\text { 5'-AGCTTGCCATCCTTGAAGAGTC-3' }\end{array}$ & AJ630649 \\
\hline TGF- $\boldsymbol{\beta}$ & $\begin{array}{l}\text { 5'-GACCTGGGATGGAAGTGG-3' } \\
\text { 5'-CAGCTGCTCACCTTGTG-3' }\end{array}$ & AM421619 \\
\hline CD8- $\boldsymbol{\alpha}$ & $\begin{array}{l}\text { 5'-CTAAGATTCGGCAAAATAACTCGA-3' } \\
\text { 5'-GATGAGGAGTAGAAGAAGAAGGCC-3' }\end{array}$ & AJ846849 \\
\hline $\mathbf{M H C}$ II- $\boldsymbol{\beta}$ & $\begin{array}{l}\text { 5'-TCAGAGTGAGCTGGCTCAGA-3' } \\
\text { 5'-GGAACCAGAATCCTTCCTGG-3' }\end{array}$ & AY994059 \\
\hline Mx & $\begin{array}{l}\text { 5'-GTCTGGAGATCGCCTCT-3' } \\
\text { 5'-GTGGATCCTGATGGAGA-3' }\end{array}$ & AM228977 \\
\hline IFN & $\begin{array}{l}\text { 5'-GGCTCTACTGGATACGATGGCT-3' } \\
\text { 5'-CTCCCATGATGCAGAGCTGTG-3' }\end{array}$ & AM765847 \\
\hline
\end{tabular}

Table 1: Primers used for immune-relevant genes detection and real-time PCR
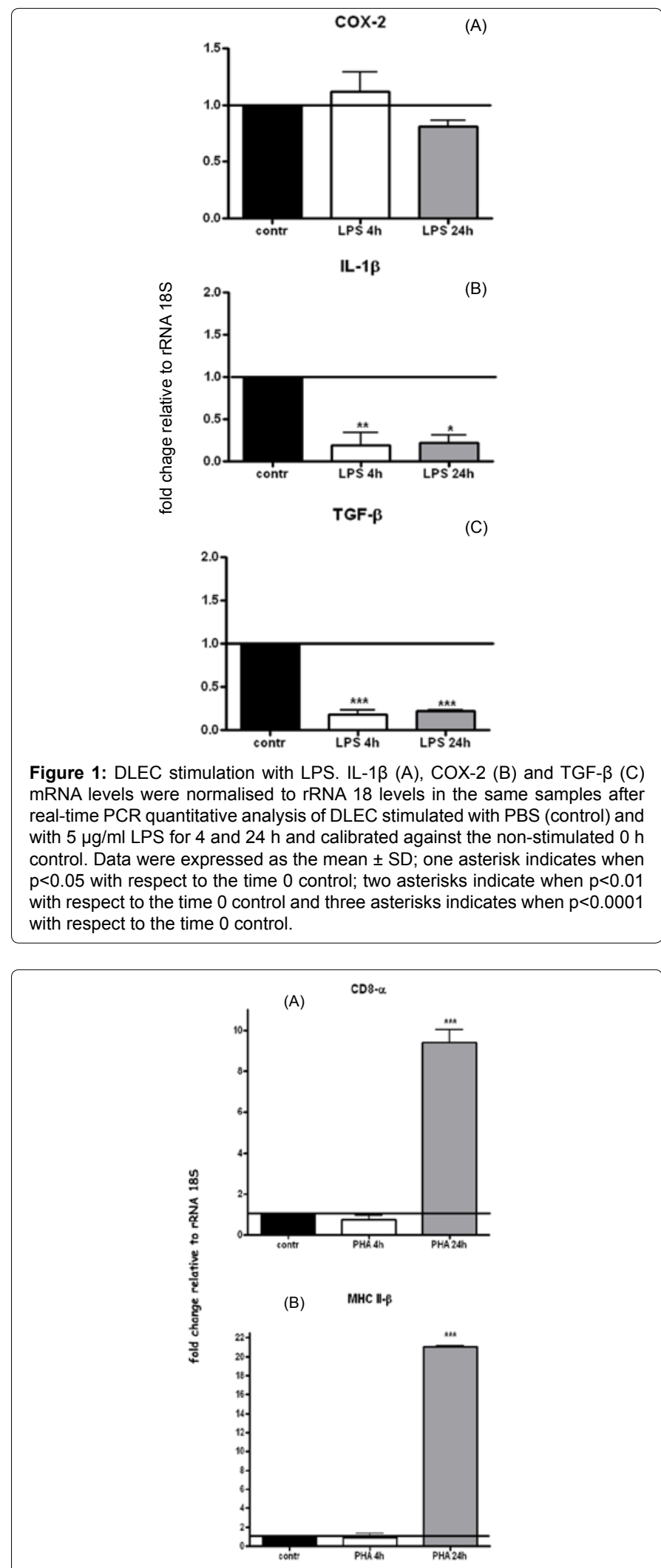

Figure 2: DLEC stimulation with PHA. CD8- $\alpha(A)$ and MHC II- $\beta$ (B) mRNA levels were normalised to rRNA 18 levels in the same samples after real-time PCR quantitative analysis of DLEC stimulated with PBS (control) and with 1 $\mu \mathrm{g} / \mathrm{ml} \mathrm{PHA}$ for 4 and $24 \mathrm{~h}$ and calibrated against the non-stimulated $0 \mathrm{~h}$ control Data were expressed as indicated for Fig. 1. 

related Gene Transcripts in the DLEC Cell Line from European Sea Bass (Dicentrarchus labrax L.). J Aquac Res Development 2:105. doi:10.4172/2155-9546.1000105

Page 3 of 4

IFN

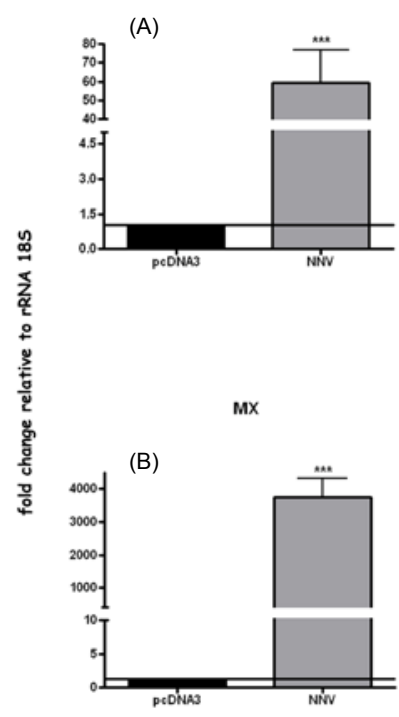

Figure 3: DLEC transfection. IFN (A) and Mx (B) mRNA levels expressed were normalised to rRNA 18 levels in the same samples after real-time PCR quantitative analysis of DLEC stimulated with void pCDNA3 plasmid (control) and with pcDNA3 plasmid containing the sequence codifying for the coat protein of the NNV and calibrated against the void plasmid. Data were expressed as indicated for Figure1.

and from the transfection experiments with TRIsure (Bioline, London, UK) following the manufacturer's instructions, resuspended in DEPC treated water and used for real-time quantitative PCR without pooling the samples coming from the different flasks. Controls for the presence of DNA contamination were performed with RT-PCR using $\beta$-actin primers that bracket an intron (Table 1).

For reverse transcription, the BioScript RNase $\mathrm{H}$ minus (Bioline, London, UK) enzyme was used with the with the protocol described before [11]. The expression level of the target genes was determined with a Mx3000 $\mathrm{P}^{\mathrm{TM}}$ real time PCR system (Agilent-Stratagene, USA) equipped with version 2.02 software and using the Brilliant SYBR Green Q-PCR Master Mix (Agilent-Stratagene, USA) following the manufacturer's instructions, with ROX as internal passive reference dye. Specific PCR primers were designed for the amplification of about 200 bp products from IL- $1 \beta$, COX-2, TGF- $\beta$, CD $8 \alpha$, MHC II- $\beta$, Mx, IFN (Table 1) and ribosomal RNA $18 \mathrm{~S}$ (Table 1), used as an house-keeping gene. $10 \mathrm{ng}$ of $\mathrm{cDNA}$ template was used in each PCR reaction. The PCR conditions were $95^{\circ} \mathrm{C}$ for $10 \mathrm{~min}$, followed by 35 cycles of $95^{\circ} \mathrm{C}$ for 45 $\mathrm{s}, 52^{\circ} \mathrm{C}$ for $45 \mathrm{~s}$ and $72^{\circ} \mathrm{C}$ for $45 \mathrm{~s}$. Triplicate reactions were performed for each template $\mathrm{CDNA}$ and the template was replaced with water in all blank control reactions. The analysis was carried out using the endpoints method option of the Mx3000 ${ }^{\mathrm{TM}}$ software that causes the collection of the fluorescence data at the end of each extension stage of amplification. A relative quantitation has been performed and a normalizer target (the ribosomal RNA transcript) is included to correct for differences in total cDNA input between samples. The levels of the target transcripts have been reported as a ratio to a reference transcript (calibrator: the time 0 control for the stimulations and the sample treated with void pcDNA3 for the transfections). The results are expressed as the mean \pm SD and the differences from the controls have been considered significant if $\mathrm{p}<0.05$ using a statistical analyses performed by the one-way ANOVA followed by the Bonferroni test. The real-time PCR products from the different experiments were examined by agarose gel electrophoresis to investigate their specificity and size.

\section{Results and Discussion}

\section{Cloning and sequencing of the selected gene of interest from DLEC}

Some inflammatory (IL-1 $\beta$, COX-2), anti-inflammatory (TGF- $\beta$ ), T-cell-marker (CD8- $\alpha$ and MHC II- $\beta$ ) and anti-viral (IFN, Mx) genes, already known in sea bass, were selected to verify their presence in the DLEC cell line. All tested molecules were found as constitutively expressed and the obtained sequences showed 100\% identity with the corresponding sea bass transcripts (data not shown).

\section{Real-time PCR quantitative analyses of the DLEC cells after stimulation and transfection}

On the DLEC cells stimulated with LPS, that should mimic an aggression of a bacterial pathogen, we investigated the modulation of IL- $1 \beta$, COX- 2 and TGF- $\beta$ for a short $(4 \mathrm{~h})$ and a longer $(24 \mathrm{~h})$ time. Real-time PCR products were loaded on agarose gels and single bands of the expected sizes were obtained. The results from the three performed experiments are shown in (Figure 1). IL-1 $\beta$ and TGFtranscripts displayed a significant decrease after both $4 \mathrm{~h}$ and $24 \mathrm{~h}$, whereas COX-2 evidenced a slight increase after $4 \mathrm{~h}$ and a decrease after $24 \mathrm{~h}$, both being non statistically significant. These data are in disagreement with the results obtained in sea bass after in vitro or in vivo stimulations as usually LPS induces an up-regulation IL- $1 \beta$ and COX-2 $[12,13]$ and with the results found in murine macrophages for TGF- $\beta$ after LPS stimulation [14] where an induction of expression have been evidenced. Moreover, LPS was a strong inducer of IL-1 $\beta$ in a rainbow trout hypodermal fibroblast cell line [15]. On the contrary, LPS fails to induce different immune-relevant genes in trout mononuclear phagocytes [16], an event that occurs downstream of toll-like receptor 4 (TLR4) in mammals.

On the DLEC cells stimulated with PHA, a mitogen agent that should stimulate the T-cells, we investigated the modulation of CD8- $\alpha$ and MHC II- $\beta$ for a short $(4 \mathrm{~h})$ and a longer $(24 \mathrm{~h})$ time. Real-time PCR products were loaded on agarose gels and single bands of the expected sizes were obtained. The results from the three performed experiments are shown in (Figure 2). Both CD8- $\alpha$ and MHC II- $\beta$ transcripts displayed a slight decrease after $4 \mathrm{~h}$ and a significant increase after 24 $\mathrm{h}$ of stimulation. These data are in agreement with the results found in mammals studying the gene expression profile of T-cells after PHA stimulation by cDNA microarray analysis [17], that showed an up-regulation of transcripts like CD8- $\alpha$ and MHC II- $\beta$ in the late generations of T-cells.

On the DLEC cells transfected with the coat protein of the NNV, we investigated the modulation of IFN and Mx. Real-time PCR products were loaded on agarose gels and single bands of the expected sizes were obtained. The results from the three performed experiments are shown in (Figure 3). Both IFN and Mx transcripts showed a significant increase after the transfection compared to the control treated with the void pcDNA3 plasmid. These data are in agreement with the results obtained in sea bass after in vivo infection with NNV [18] that showed an high increase of IFN and Mx expression in the first hours after pathogen invasion.

The DLEC did not reproduce the response of sea bass after LPS stimulation for the regulation of inflammatory cytokines and it could be due to the lack of TLR4-mediated endotoxin recognition molecules in the cell line. On the contrary, the target genes linked to T-cell responses showed a behaviour comparable to other transcripts, like CD4, in sea bass [19]. Finally, the anti-viral genes analysed after the transfection 
Citation: Buonocore F, Randelli E, Lorenzen N, Einer-Jensen K, Scapigliati G (2011) Analysis of the Expression and Modulation of Selected Immunerelated Gene Transcripts in the DLEC Cell Line from European Sea Bass (Dicentrarchus labrax L.). J Aquac Res Development 2:105. doi:10.4172/2155-9546.1000105

Page 4 of 4

with the NNV coat protein resulted up-regulated in a similar manner to sea bass homologues. In conclusion, these data evidenced the immune responses of DLEC to specific PAMPs and the importance of this cell line for both fish immunology and aquaculture studies avoiding the use of live test animals.

\section{Acknowledgements}

Authors are indebted to Dr. M. Tiberi for the transfection experiments and Dr. Simona Cozza for the real-time analyses.

\section{References}

1. Lakra WS, Raja Swaminathan T, Joy KP (2010). Development, characterization, conservation and storage of fish cell lines: a review. Fish Physiol Biochem, in press (DOI 10.1007/s10695-010-9411-x).

2. Lai YS, John JAC, Lin CH, Guo IC, Chen SC, et al. (2003). Establishment of cell lines from a tropical grouper, Epinephelus awoara (Temminck and Schlegel), and their susceptibility to grouper irido and nodaviruses. J Fish Dis 26: 31-42.

3. Parameswaran V, Ahmed VPI, Shukla R, Bhonde RR, Hameed ASS (2007). Development and characterization of two new cell lines from milkfish (Chanos chanos) and grouper (Epinephelus coioides) for virus isolation. Mar Biotechnol 9: 766-775.

4. Wen CM, Lee CW, Wang CS, Cheng YH, Huang HY (2008). Dvelopmet of two cell lines from Epinephelus coioides brain tissue for characterization of betanodavirus and megalocytivirus infectivity and propagation. Aquaculture 278: 14-21.

5. Ahmed IVP, Chandra V, Sudhakaran R, Rajesh Kumar S, Sarathi M, et al (2009). Development and characterization of cell lines derived from rohu, Labeo rohita (Hamilton), and catla, Catla catla (Hamilton). J Fish Dis 32: 211 218.

6. Ku CC, Teng YC, Wang CS, Lu CH (2009). Establishment and characterization of three cell lines derived from the rockfish grouper Epinephelus quoyanus: Use for transgenic studies and cytotoxicity testing. Aquaculture 294: 147-151.

7. Buonocore F, Libertini A, Prugnoli D, Mazzini M, Scapigliati G (2006) Production and characterization of a continuous embryonic cell line from sea bass (Dicentrarchus labrax L.). Marine Biotech 8: 80-85.
8. Servili A, Bufalino MR, Nishikawa R, Sanchez de Melo I, Munoz-Cueto JA, et al. (2009). Establishment of long term cultures of neural stem cells from adult sea bass Dicentrarchus labrax. Comp Biochem Physiol Part A 152: 245-254.

9. Pearson WR, Lipman DJ (1988). Improved tools for biological sequence comparison. Proc. Natl. Acad. Sci. USA 85: 2444-2448.

10. Altschul SF, Gish W, Miller W, Myers E, Lipman DJ (1990). Best local alignment search tool. J Mol Biol 215: 403-410.

11. Buonocore F, Randelli E, Bird S, Secombes CJ, Facchiano A, et al. (2007) Interleukin-10 expression by real-time PCR and homology modelling analysis in the European sea bass (Dicentrarchus labrax L.). Aquaculture 270: 512-522.

12. Scapigliati G, Buonocore F, Bird S, Zou J, Pelegrin P, et al. (2001). Phylogeny of cytokines: molecular cloning and expression analysis of sea bass Dicentrarchus labrax interleukin-1 beta. Fish Shellfish Immunol 11: 711-726.

13. Buonocore F, Randelli E, Casani D, Mazzini M, Cappuccio I, et al. (2005) cDNA cloning and expression analysis of a cyclooxygenase-2 from sea bass (Dicentrarchus labrax L.) after vaccination. Aquaculture 245: 301-310.

14. Feng WG, Chang ZL (1998). Expression of cytokine mRNA during immunomodulation murine suppressor macrophages. Cell Res 8: 317-322.

15. Ingerslev HC, Ossum CG, Lindenstrom T, Nielsen ME (2010). Fibroblasts express immune relevant genes and are important sentinel cells during tissue damage in rainbow trout (Oncorhynchus mykiss). PLoS One 2010; 5: e9304.

16. Iliev DB, Roach JC, Mackenzie S, Planas JV, Goetz FW (2005). Endotoxin recognition: In fish or not in fish? FEBS Letters 579, 6519-6528.

17. Li Y, Wong KK, Matsueda S, Efferson CL, Chang DZ, et al. (2006). Mitogen stimulation activates different signalling pathways in early- and late-divided $T$ cells as revealed by cDNA microarray analysis (2006). Int J Mol Med 18: 1127 1139.

18. Scapigliati G, Buonocore F, Randelli E, Casani D, Meloni S, et al. (2010). Cellular and molecular immune responses of the sea bass (Dicentrarchus labrax) experimentally infected with betanodavirus. Fish Shellfish Immunol 28 303-311.

19. Buonocore F, Randelli E, Casani D, Guerra L, Picchietti P, et al. (2008). A CD4 homologue in sea bass (Dicentrarchus labrax): molecular characterization and structural analysis. Mol Immunol 45: 3168-3177. 